\title{
DISTURBANCES OF CYSTINE METABOLISM IN LIVER DISEASE
}

\author{
By J. M.WALSHE ${ }^{1}$ AND B. SENIOR 2 \\ (From the Medical Unit, University College Hospital Medical School, London, England)
}

(Submitted for publication May 13, 1954 ; accepted October 27, 1954)

The urinary excretion of cystine, as determined on the polarograph, varies, in normal adults, between 40 and $80 \mathrm{mg}$. daily (1). It may be increased either as a result of a low renal threshold for cystine or a raised plasma cystine concentration. Cystinuria due to a low renal threshold occurs in 'classical cystinuria,' the Fanconi syndrome and hepatolenticular degeneration (2). In such conditions the excretion of cystine is usually large, 0.5 to $1.0 \mathrm{~g}$. daily, and is associated with other characteristic changes in the pattern of amino acids excreted. A moderately increased excretion of cystine has been described in patients with liver disease (3-5) and this has been shown, by paper chromatography, to result from a raised plasma cystine concentration. It has been suggested that the increased urinary cystine in these patients might form a sensitive index of impaired amino acid metabolism (6).

Using the quantitatively more accurate method of polarography for cystine assay we have reinvestigated the plasma level and urinary output of cystine in cases of liver disease. In addition we have carried out cystine and cysteine tolerance tests comparing the results found in patients with chronic liver injury with those found in normal subjects.

\section{METHODS}

Polarography (7) was used to measure the concentration of cystine in plasma and the output of cystine in urine. Technical details have already been published (8). This method does not distinguish between cystine and cysteine as the S-S linkage is reduced to the $\mathrm{S}-\mathrm{H}$ form in the polarizing cell. It is improbable that cysteine, following its ingestion, would remain for long in the reduced state in the plasma as the oxygen present, at normal plasma $\mathrm{pH}$, would rapidly cause its conversion to cystine. This problem has been discussed in more detail elsewhere (8). Recoveries of cystine added to plasma

\footnotetext{
1 Stothert Research Fellow of The Royal Society.

2 Present address: Department of Clinical Medicine, University of Cape Town. In receipt of a personal grant from the Medical Research Council.
}

were accurate to \pm 10 per cent. Comparing our results with those of Stein, Bearn, and Moore (9), who used the method of elution chromatography, we find that the normal plasma cystine levels are very similar; their figures for the 24-hour excretion of cystine in normal human urine, however, are consistently lower $(9,10)$ than those that we have found or were found by Reed (1). Measurable quantities of glutathione are absent from normal human plasma and urine. Even if, under the present experimental conditions, it should appear, the polarographic method as used, with the cobaltous ion as catalyst, does not determine glutathione (11). Possibly some cystine containing peptides may produce a catalytic polarographic wave at the same voltage as cystine itself. Unfortunately there is no feasible way to check this directly with the polarograph. Paper chromatographic studies have been made of both plasma and urine of normal and cystinuric subjects after feeding either cystine or cysteine. These showed changes in the cystine concentration roughly paralleling the polarographic analysis after similar feeding experiments done, in some cases, on the same subjects $(8,12)$. Likewise some of the experiments described here on patients with liver disease have also been checked by paper chromatographic analysis. No evidence has been obtained for the presence of cystine containing peptides in plasma or urine. In view of the slight doubt that our plasma cystine levels are due to cystine or to a combination of cystine with cysteine or, in the case of urine, partly to an unidentified complex of cystine we will refer to the substance throughout as 'cystine.'

Observations were made on normal subjects and on patients with both acute and chronic liver disease. The important clinical features and biochemical findings of the latter are given in Table I. The 24-hour excretion of 'cystine' in the urine was estimated from 19 patients with cirrhosis on 90 occasions, from 10 patients with acute hepatitis on 16 occasions and from one patient with acute hepatic necrosis on 8 occasions. Forty-six determinations were made of the fasting plasma 'cystine' level on 18 patients with cirrhosis. The control observations consisted of 25 determinations of the 24-hour output of 'cystine' on 25 normal adults and 50 fasting plasma 'cystine' levels on a further 16 normal subjects, these latter have also been described elsewhere (8). All patients were on the usual ward diet and none were receiving protein supplements.

Experiments were carried out in which 1-cystine, $5.0 \mathrm{~g}$., was given by mouth to fasting patients; the plasma 'cystine' level was estimated immediately before and at 
DISTURBANCES OF CYSTINE METABOLISM IN LIVER DISEASE

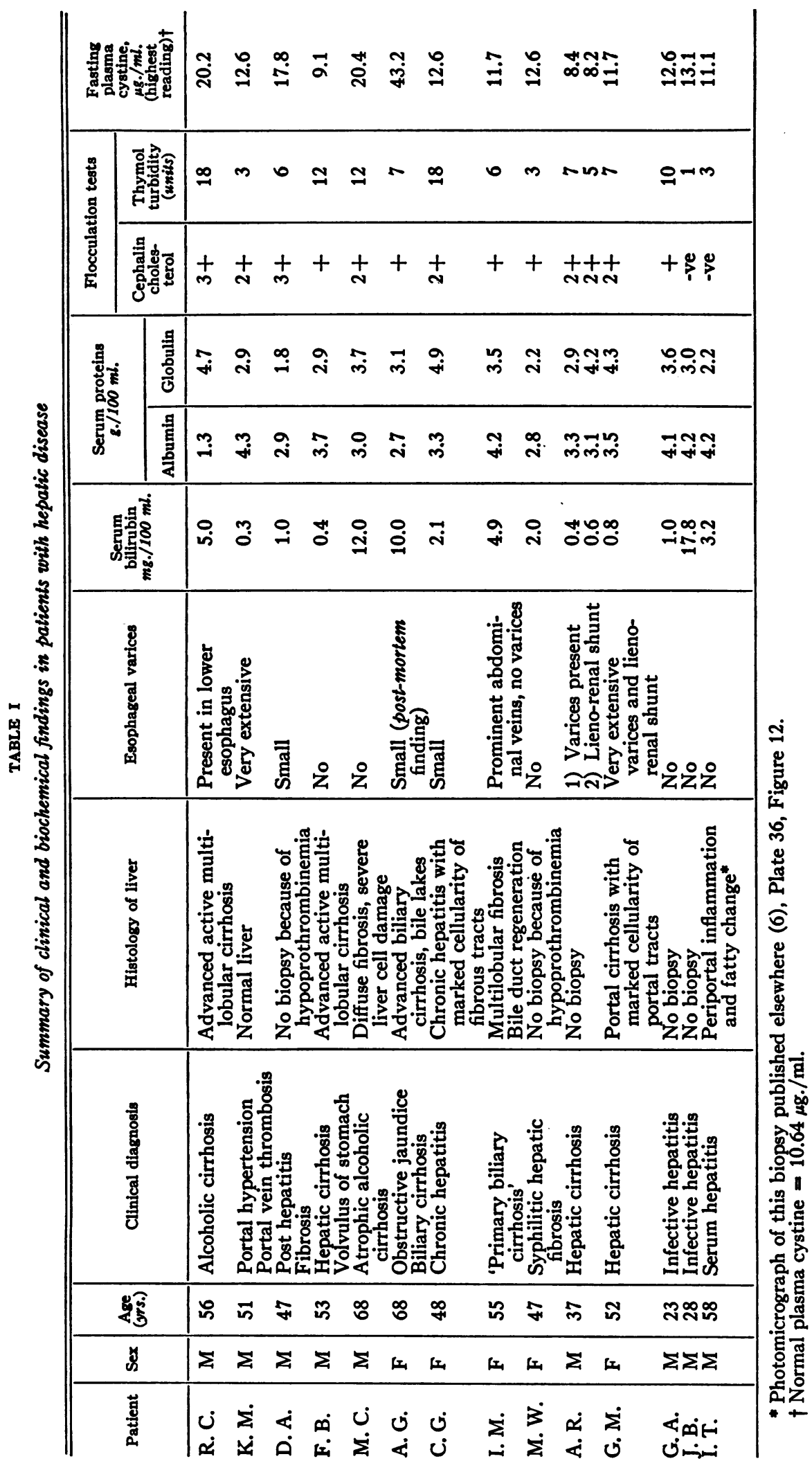


one-half, one, two, four, and six hours afterwards. The same measurements were also made after the ingestion of $3.0 \mathrm{~g}$. of 1-cysteine $\mathrm{HCl}$. For control observations a similar series of tests were carried out on normal subjects. The smaller dose of cysteine $\mathrm{HCl}$ was chosen as this amino acid has a tendency to produce nausea and vomiting, which we wished to avoid in patients with liver injury, and because, in experimental animals, single large doses may give rise to toxic side effects (13).

\section{RESULTS}

\section{1) The fasting plasma 'cystine' concentration}

The normal figures varied between 6.7 and 14.4 $\mu g$. per ml. with a mean of $10.64 \pm 1.87$. In patients with hepatic cirrhosis the fasting plasma 'cystine' level varied between 5.6 and $43.2 \mu \mathrm{g}$. per $\mathrm{ml}$. with a mean of $13.7 \pm 5.75$. In general it was found that in patients with cirrhosis the higher plasma 'cystine' levels were associated with the more severe degrees of liver damage: The patient with a 'cystine' concentration of $43.2 \mu \mathrm{g}$. per $\mathrm{ml}$. was in fact in the terminal stage of hepatic coma at the time. These results are expressed as a histogram, Figure 1.

Sufficient observations on patients with acute hepatitis have not been made to allow of any conclusions, but in one case of massive hepatic necrosis the plasma 'cystine' reached a concentration of $70 \mu \mathrm{g}$. per $\mathrm{ml}$. shortly before death.

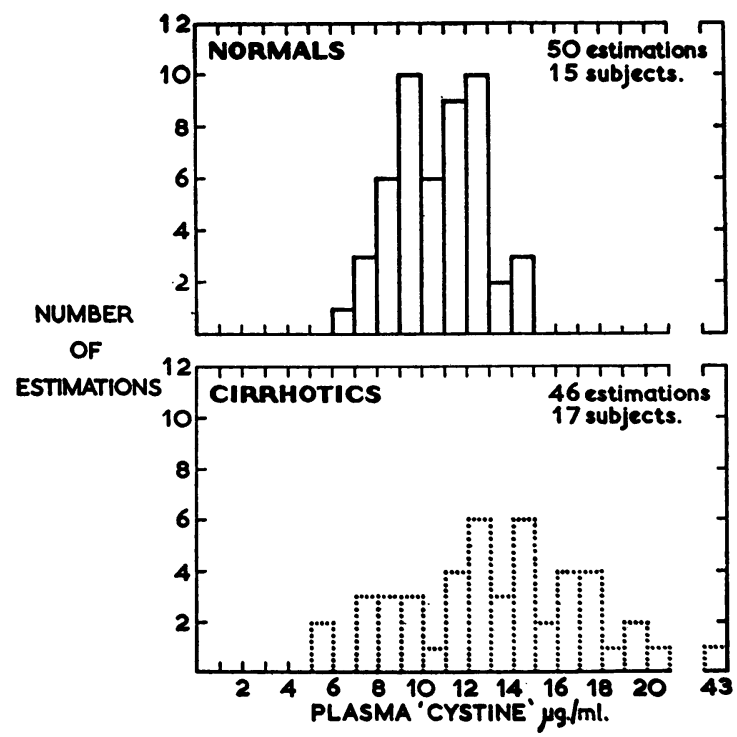

Fig. 1. Histogram Comparing the Fasting Plasma Cystine Level in Normal Subjects with a Similar Sertes of Results from Patients with Hepatic Cirreosis
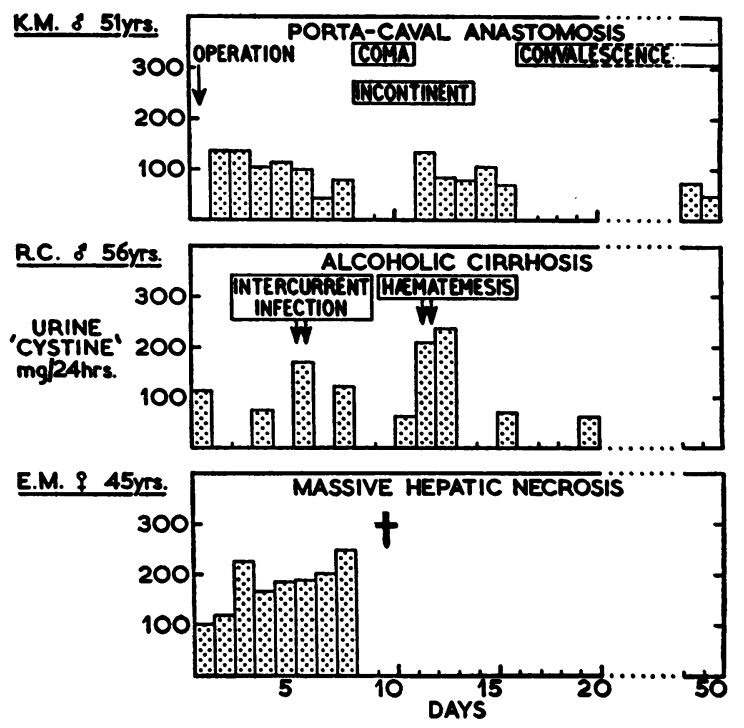

Fig. 2. Daily Cystine Excretion in Three Patients; Two, K. M. and R. C., with Chronic Liver Damage and One, E. M., with Massive Hepatic NeCrosis

This shows the variations which can occur in the urinary cystine corresponding approximately with the clinical condition of the patient.

\section{2) The excretion of 'cystine' in the urine}

In 13 adult normal males the output of 'cystine' varied between 43 and $70 \mathrm{mg}$. per 24 hours, with a mean of $61 \mathrm{mg}$. In 12 adult normal females the range was between 28 and $53 \mathrm{mg}$. of 'cystine' with a mean of $44 \mathrm{mg}$. per 24 hours. In patients with cirrhosis the 24-hour excretion of 'cystine' was measured on 90 separate occasions in 19 different patients (10 male, 9 female), the majority being represented by more than one urine specimen. As the output of 'cystine' was not constant for any given patient but fluctuated with the severity of the illness (Figure 2) each estimation is treated as a separate entity on the histogram (Figure 3 ). The 10 male patients provided 59 urine specimens, the 'cystine' excretion varied between 38 and 234 mg. per 24 hours with a mean of $81 \mathrm{mg}$. From the 9 female patients 31 urine specimens were obtained, the range of 'cystine' excretion was from 32 to $150 \mathrm{mg}$. with a mean of $65 \mathrm{mg}$. per 24 hours. The mean for each group shows an increase in 'cystine' excretion of $20 \mathrm{mg}$. per 24 hours when compared with the corresponding average normal figure. This difference, though appreciable, does not result in a sharp separation between normal 


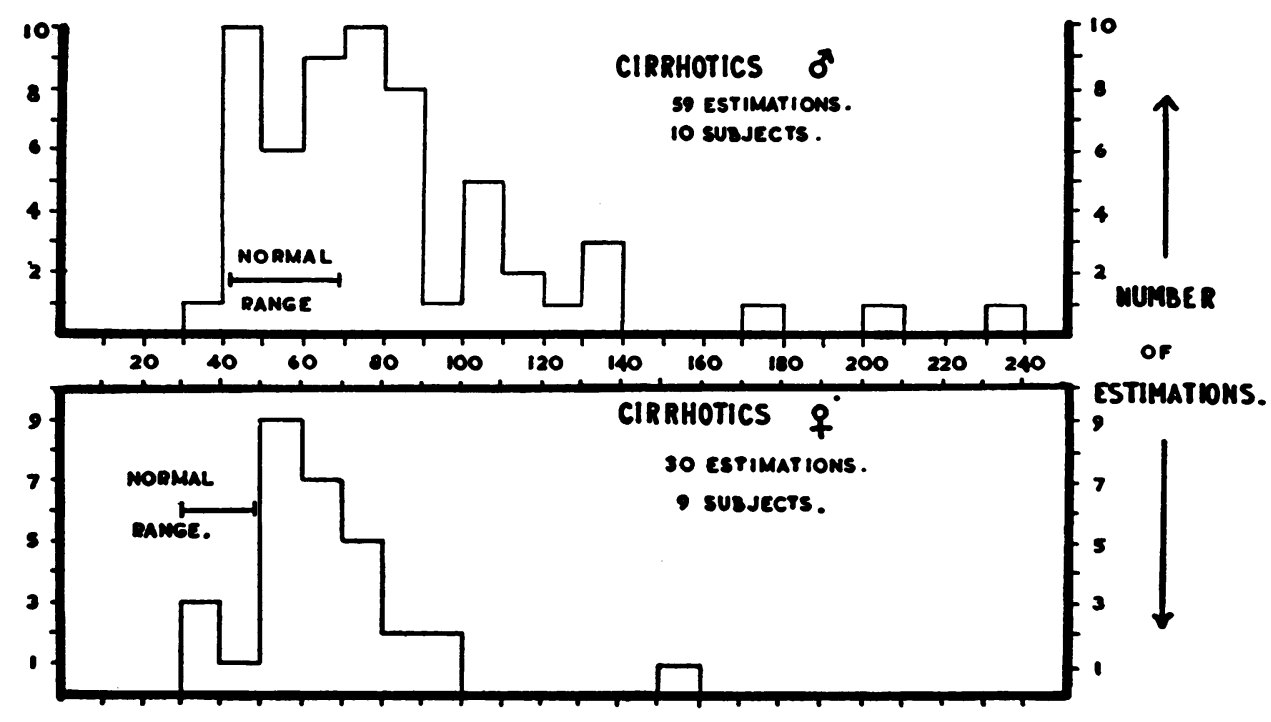

URINE 'CYSTINE' mg. 24 HOURS.

Fig. 3. Histogram Showing the Range of Variation in the 24-Hour Excretion of Cystine in Male and Female Patients with Hepattc Cirrhosis

subjects and patients with cirrhosis since the 'cystine' excretion in approximately half the estimations on the latter fall within the normal range. There appeared to be a definite correlation between the 'cystine' excretion and the severity of the liver injury; the highest figures for urinary cystine excretion being found in those patients with the most severe illness.

In 10 patients with acute hepatitis the 'cystine' excretion during the acute phase of the illness was elevated, averaging $97 \mathrm{mg}$. and varying between 76 and $134 \mathrm{mg}$. per 24 hours; this returned rapidly to within normal limits during convalescence, the mean figure at this stage being $56 \mathrm{mg}$. and the range between 42 and $68 \mathrm{mg}$. per 24 hours. In one patient with massive hepatic necrosis the excretion of 'cystine' rose to $250 \mathrm{mg}$. per 24 hours two days before death.

TABLE II

Plasma cystine concentration after feeding $5.0 \mathrm{~g}$. of cystine

\begin{tabular}{|c|c|c|c|c|c|c|}
\hline \multirow[b]{2}{*}{ Patient } & \multicolumn{6}{|c|}{ Plasma cystine concentration, $\mu g . / \mathrm{ml}$. } \\
\hline & Fasting & Hour & 1 Hour & 2 Hours & 4 Hours & 6 Hours \\
\hline \multicolumn{7}{|c|}{ (a) To patients with hepatic cirrhosis } \\
\hline $\begin{array}{l}\text { K. M. } \\
\text { F. B. } \\
\text { M. W. } \\
\text { A. G. } \\
\text { C. G. } \\
\text { D. A. }\end{array}$ & $\begin{array}{r}12.6 \\
9.1 \\
9.0 \\
7.2 \\
8.0 \\
17.8\end{array}$ & $\begin{array}{r}10.0 \\
12.6 \\
12.7 \\
9.0 \\
8.2 \\
15.8\end{array}$ & $\begin{array}{l}10.8 \\
13.1 \\
18.6 \\
14.0 \\
12.7 \\
16.2\end{array}$ & $\begin{array}{l}16.1 \\
16.2 \\
16.3 \\
17.5 \\
13.5 \\
25.0\end{array}$ & $\begin{array}{l}15.7 \\
15.7 \\
19.3 \\
13.1 \\
13.0 \\
23.0\end{array}$ & $\begin{array}{l}13.0 \\
12.2 \\
15.3 \\
10.8 \\
15.5 \\
25.6\end{array}$ \\
\hline \multicolumn{7}{|c|}{ (b) To patients with acute hepatitis } \\
\hline $\begin{array}{l}\text { I. T. } \\
\text { J. B. } \\
\text { G. A. }\end{array}$ & $\begin{array}{r}7.5 \\
13.1 \\
12.6\end{array}$ & $\begin{array}{r}7.5 \\
12.1 \\
13.1\end{array}$ & $\begin{array}{l}15.5 \\
15.2 \\
12.8\end{array}$ & $\begin{array}{l}13.8 \\
14.5 \\
17.1\end{array}$ & $\begin{array}{l}\overline{14.5} \\
16.2\end{array}$ & $\begin{array}{r}10.1 \\
9.0 \\
-\end{array}$ \\
\hline $\begin{array}{l}\text { Average normal } \\
\text { Maximum normal } \\
\text { Minimum normal }\end{array}$ & $\begin{array}{r}10.8 \\
12.6 \\
7.8\end{array}$ & $\begin{array}{r}12.8 \\
16.9 \\
9.6\end{array}$ & $\begin{array}{r}13.3 \\
16.2 \\
9.0\end{array}$ & $\begin{array}{l}13.3 \\
14.5 \\
12.6\end{array}$ & $\begin{array}{r}12.7 \\
15.2 \\
9.0\end{array}$ & $\begin{array}{r}11.3 \\
13.2 \\
9.0\end{array}$ \\
\hline
\end{tabular}




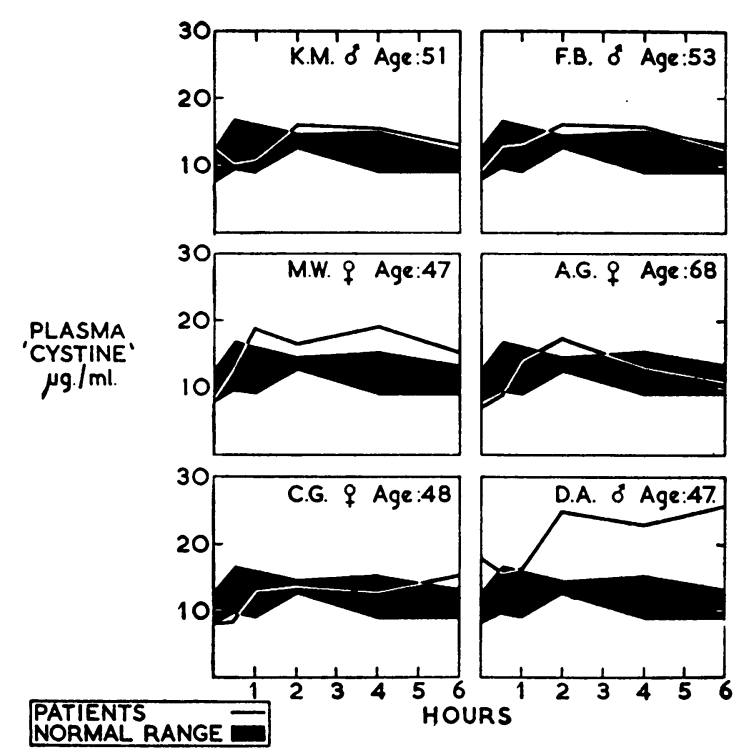

Fig. 4. Cystine Tolerance Tests in Patients with Hepatic CirRhosis

Cystine $5.0 \mathrm{~g}$. was given to each patient immediately after the fasting blood was drawn. The control results show the extreme range of normal variation in seven similar studies on normal subjects.

\section{3) Effect of feeding 1-cystine, $5.0 \mathrm{~g}$., to patients with hepatic cirrhosis}

The results are given in Table II and Figure 4; the control observations were obtained from seven similar studies on normal subjects and are published in detail elsewhere (8). In five of the six patients the cystine tolerance curve deviated little from that found in the controls although the peak was somewhat delayed. In the case of D.A. the fasting plasma 'cystine' level was elevated and the initial rise in response to the loading dose of cystine was exaggerated and was maintained throughout the six-hour experimental period. This man had advanced cirrhosis following an attack of serum hepatitis. Clinically he was the most seriously ill patient in this group.

\section{4) Effect of feeding 1-cysteine $\mathrm{HCl}, 3.0 \mathrm{~g}$, to patients with hepatic cirrhosis}

It was intended to give $6.0 \mathrm{~g}$. of 1-cysteine $\mathrm{HCl}$ containing approximately an equimolecular amount of sulphur to $5.0 \mathrm{~g}$. of cystine. Eventually, for reasons stated earlier, it was decided to give a smaller dose of cysteine to the patients with cirrhosis. As a pilot experiment $2.0 \mathrm{~g}$. of 1-cysteine $\mathrm{HCl}$ was given; this produced no toxic symptoms but did result in a sharp rise in the plasma 'cystine' concentration. The dose given in subsequent tests, and also to the control subjects, was $3.0 \mathrm{~g}$. The average figure for the four normal subjects shows that the plasma 'cystine' rose from a fasting level of $9.0 \mu \mathrm{g}$. per ml. to $15.3 \mu \mathrm{g}$. per ml. at one hour but returned to the fasting level by the end of two hours. In the patients with cirrhosis the rise was very much greater. In the case of M. C. the peak 'cystine' concentration, reached at one hour, was $60 \mu \mathrm{g}$. per $\mathrm{ml}$. and it exceeded $30 \mu \mathrm{g}$. per $\mathrm{ml}$. in all of the cases investigated. The results are given in detail in Table III and also in Figure 5.

Of the five patients with cirrhosis fed cysteine two (G. M. and A. R.) had lieno-renal anastomoses which had been constructed for the relief of portal

TABLE III

Plasma 'cystine' concentration after feeding $3.0 \mathrm{~g}$. of 1-Cysteine $\mathrm{HCl}$

\begin{tabular}{|c|c|c|c|c|c|c|}
\hline \multirow[b]{2}{*}{ Patient } & \multicolumn{6}{|c|}{ Plasma 'cystine' concentration, $\mu \mathrm{g} . / \mathrm{ml}$. } \\
\hline & Fasting & Hour & 1 Hour & 2 Hours & 4 Hours & 6 Hours \\
\hline \multicolumn{7}{|c|}{ (a) To patients with hepatic cirrhosis } \\
\hline $\begin{array}{l}\text { C. G. } \\
\text { I. M. } \\
\text { M. C. } \\
\text { G. M. } \\
\text { A. R. }\end{array}$ & $\begin{array}{r}12.6 \\
11.7 \\
16.7 \\
11.7 \\
8.2\end{array}$ & $\begin{array}{l}47.6 \\
56.7 \\
52.2 \\
17.5 \\
33.3\end{array}$ & $\begin{array}{l}42.5 \\
49.3 \\
60.0 \\
37.5 \\
42.5\end{array}$ & $\begin{array}{l}23.4 \\
46.5 \\
42.2 \\
28.1 \\
27.1\end{array}$ & $\begin{array}{l}16.2 \\
25.6 \\
27.2 \\
19.5 \\
27.8\end{array}$ & $\begin{array}{l}14.2 \\
18.6 \\
22.4 \\
15.6 \\
17.8\end{array}$ \\
\hline \multicolumn{7}{|c|}{ (b) To controls } \\
\hline $\begin{array}{l}\text { M.S. } \\
\text { J. C. } \\
\text { E. S. } \\
\text { T. G. }\end{array}$ & $\begin{array}{r}9.4 \\
6.5 \\
11.1 \\
9.3\end{array}$ & $\begin{array}{r}12.4 \\
9.2 \\
19.7 \\
10.9\end{array}$ & $\begin{array}{l}19.9 \\
12.9 \\
11.3 \\
17.0\end{array}$ & $\begin{array}{r}12.1 \\
9.1 \\
12.5 \\
10.8\end{array}$ & $\begin{array}{r}8.7 \\
9.9 \\
14.1 \\
8.7\end{array}$ & $\begin{array}{r}10.3 \\
9.5 \\
8.4 \\
8.3\end{array}$ \\
\hline
\end{tabular}




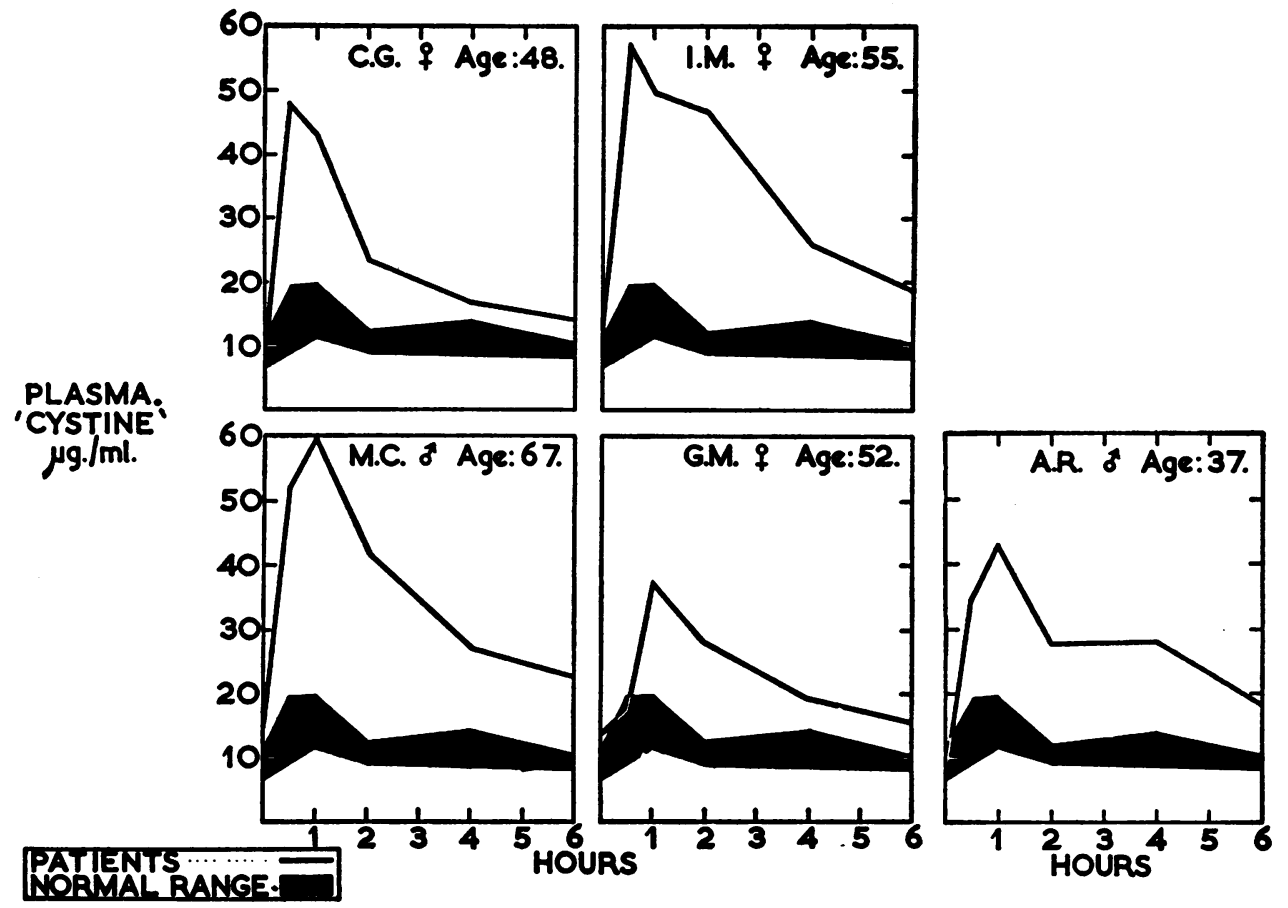

Fig. 5. Cysteine Tolerance Tests in Five Patients with Hepatic Cirrhosis

1-Cysteine $\mathrm{HCl} 3.0 \mathrm{~g}$. was given immediately after the fasting blood was drawn. The control results show the extreme range of variation on four normal subjects.

hypertension. The results in these two cases did not differ materially from those found in the three patients with cirrhosis but no clinical evidence of portal hypertension. The presence of these large portal-systemic anastomotic veins did not lead to an increased abnormality in the shape of the cysteine tolerance curves.

\section{5) 'Cystine' clearance in patients with liver injury}

In normal subjects the urine excretion of 'cystine' varies directly with the plasma concentration (8). In certain of the cystine and cysteine tolerance tests carried out on patients with cirrhosis urine samples were collected during the experimental period and it was found that the "cystine' clearance was the same in these patients as in the controls, that is around 2 to $4 \mathrm{ml}$. per min. at all plasma concentrations investigated. These results have been expressed graphically (Figure 6), plasma' cystine' concentration being plotted against the minute excretion of 'cystine.' The figures show a highly significant correlation between the plasma level and the urine excretion of 'cystine,' the correlation coefficient is $r=0.8020$.

The figures in this graph do not include those from the cysteine tolerance test on C. G. in which urine 'cystine' was estimated. In this experiment at the highest plasma 'cystine' levels there was no

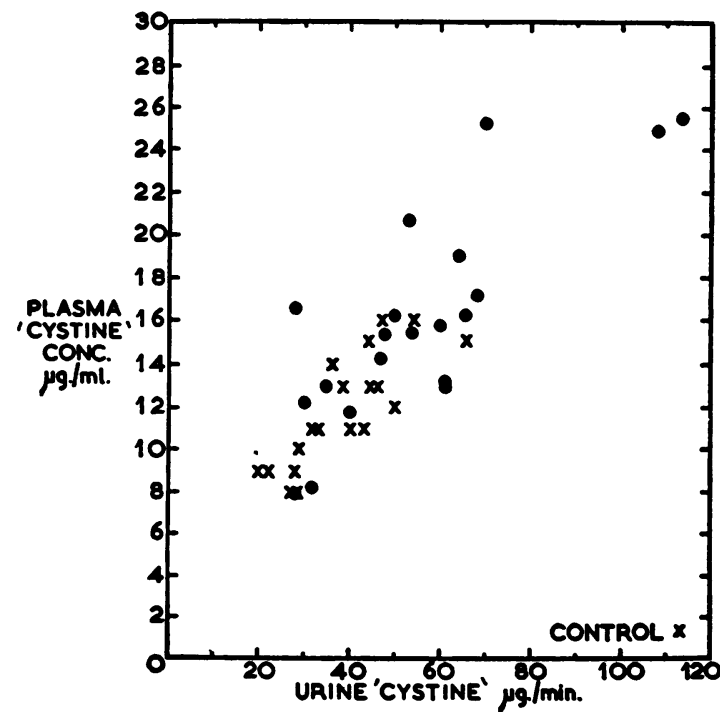

Fig. 6. Graph Showing the Relationship between the Plasma 'Cystine' Concentration and the Minute Excretton of 'Cystine' in the Urine (The CorrelaTION Coefficient is $r=0.80$ )

= Patients with hepatic cirrhosis. $x=$ Normal controls. 
TABLE IV

\begin{tabular}{|c|c|c|c|c|c|c|}
\hline \multirow[b]{2}{*}{$\begin{array}{c}\text { Time } \\
\text { in } \\
\text { hours }\end{array}$} & \multicolumn{3}{|c|}{ D. A. (5.0 g. cystine) } & \multicolumn{3}{|c|}{ C. G. (3.0 g. 1-cysteine $\mathrm{HCl})$} \\
\hline & $\begin{array}{l}\text { Plasma } \\
\text { 'cystine' } \\
\mu 8 . / m l .\end{array}$ & $\begin{array}{c}\text { Urine } \\
\text { 'cystine' } \\
\mu_{8 . / m i n .}\end{array}$ & $\begin{array}{l}\text { Clearance } \\
\text { ml./min. }\end{array}$ & $\begin{array}{l}\text { Plasma } \\
\text { "cystine' } \\
\mu \mathrm{m} . / \mathrm{ml} .\end{array}$ & $\begin{array}{c}\text { Urine } \\
\text { cystine' } \\
\mu y . / m i n .\end{array}$ & $\begin{array}{l}\text { Clearance } \\
\text { ml./min. }\end{array}$ \\
\hline \multirow{6}{*}{$\begin{array}{l}0 \\
1 \\
1 \\
1 \\
2 \\
3 \\
4 \\
5 \\
6 \\
7\end{array}$} & 17.8 & 27.0 & 1.5 & \multirow{3}{*}{$\begin{array}{l}12.6 \\
47.6 \\
42.5 \\
23.4\end{array}$} & 28.8 & 2.3 \\
\hline & $\begin{array}{l}15.8 \\
16.2\end{array}$ & 60.0 & 3.8 & & 66.6 & 1.4 \\
\hline & 25.0 & 1 & 4.3 & & 78.8 & 3.4 \\
\hline & 23.0 & 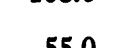 & 21 & \multirow{3}{*}{$\begin{array}{l}16.2 \\
14.2\end{array}$} & 100 & \\
\hline & 256 & 30.0 & 2.4 & & 49.8 & 3.1 \\
\hline & & 112.5 & 4.4 & & 47.2 & 3.3 \\
\hline
\end{tabular}

very great increase in the minute excretion of 'cystine'; this is particularly obvious when the results are compared with those found in D. A., the only patient who showed a marked rise in the plasma 'cystine' level after the ingestion of cystine (see Table IV). It was stated earlier that cysteine is unlikely to exist as such in the blood but it remains possible that the severe liver damage in C. G. resulted in a slower oxidation of the fed cysteine. If, as is also possible, cysteine is reabsorbed more readily than cystine by the renal tubule this would account for the lower minute excretion of 'cystine' by C. G. at the very high blood levels achieved and also for the rising urine excretion co-incident with the falling blood level during the latter part of the test period.

\section{DISCUSSION}

In patients with hepatic cirrhosis the fasting plasma 'cystine' level is frequently increased as is the 24-hour excretion of 'cystine.' In the normal individual the amount of 'cystine' excreted in the urine depends directly on the plasma concentration (8) and our results indicate that this also holds for patients with liver injury. The increase in the urinary 'cystine' in patients with acute hepatitis and cirrhosis therefore simply reflects the raised concentration of 'cystine' in the plasma. In general the higher plasma levels of 'cystine' occurred in those patients with the most marked evidence of severe parenchymal liver damage. The quantities of 'cystine' excreted by the more severely ill patients were of the same order that Harris and Warren (14) found in heterozygous cystinuric subjects. However the urine of patients with liver disease did not show the charac- teristic 'cystine, lysine pattern' of amino acid excretion of classical cystinuria but did show other abnormalities of amino acid excretion which have been described elsewhere (6).

In only one of the six patients with hepatic cirrhosis and impaired tests of liver function (D. A.) did the cystine tolerance curve differ significantly from normal. The explanation may be that cystine, which is very insoluble, is slowly absorbed from the gut and does not reach the liver in high concentration. It cannot act, therefore, as a significant load and a markedly abnormal tolerance curve is not produced except in the presence of very severe liver damage. Intravenous administration of cystine would be necessary to clarify this point but because of its extreme insolubility at body $\mathrm{pH}$ this is impracticable.

Cysteine, being very soluble, is rapidly absorbed and presumably reaches the liver in relatively high concentration either as cysteine or as cystine. Consequently $3.0 \mathrm{~g}$. of 1-cysteine $\mathrm{HCl}$ produced a greater percentage rise in the plasma 'cystine' level of normal subjects than did $5.0 \mathrm{~g}$. of cystine. Other workers have reported results similar to these, on normal subjects, and have offered the same explanation $(8,12,15)$. These authors pointed out that this was also the probable explanation of the results of the feeding experiments of Brand, Cahill, and Harris (16) who, however, analyzed only urine for cystine and interpreted their results differently. The patients with cirrhosis fed $3.0 \mathrm{~g}$. of 1-cysteine $\mathrm{HCl}$ all showed a rise in the plasma level markedly greater than that produced by the same dose in the control subjects. This phenomenon could be due either to a reduced ability on the part of the liver to metabolize cystine (or possibly only cysteine) or to 
the portal blood by-passing the liver via collateral venous channels, which can often be demonstrated in such patients. The available evidence supports the former theory. Large portal-systemic anastomotic veins in C. G. or I. M. were not detected at the time of the test and none were found at a subsequent post mortem examination on $\mathrm{M}$. C. In the two patients with lieno-renal shunts (G. M. and A. R.) the peak 'cystine' levels in the cysteine tolerance curves were lower than in the other three patients. It is more likely, therefore, that the high levels of plasma 'cystine' found indicate a reduced ability on the part of the liver to metabolize cystine (or possibly only cysteine) at the normal rate, probably due to damage to one or more of the enzyme systems specifically handling cystine in the liver.

In these experiments only 'cystine' metabolism has been studied quantitatively both in the fasting state and after the stress of an oral load and no conclusions can be drawn therefore, from this work, about the metabolism of other amino acids. The possibility remains that in the course of progressive hepatic disease, as different enzyme systems are affected, so the ability of the liver to utilize individual amino acids becomes impaired. Chromatographic studies reported elsewhere also support this theory (6). Cystine however appears to be one of the first amino acids to show disturbed metabolism in liver disease.

\section{SUMMARY}

1. The plasma 'cystine' concentration and urinary 'cystine' excretion have been measured in patients with acute and chronic liver disease, using a polarographic method of determination.

2. Comparison with the normal shows that: 1) The average figure for the plasma 'cystine' level is higher for patients with hepatic cirrhosis and shows a wide range of variation. 2) The average output of 'cystine' in the urine per 24 hours is greater in the patients with liver disease. 3) The increased output of 'cystine' is directly due to the raised plasma concentration and not to any alteration in the renal clearance. The higher figures for both plasma and urine are found in those patients with the more severe liver injury.

3. Tolerance tests have been carried out in which cystine or cysteine were fed to patients with chronic liver injury and the results compared with similar tests on normal subjects. Only in very severe liver damage does the ingestion of cystine produce an abnormal rise in the plasma 'cystine' level. On the other hand cysteine caused markedly abnormal tolerance curves in all the patients so investigated.

4. The abnormal plasma 'cystine' levels following the ingestion of cysteine appear to be due to liver damage and not to portal blood by-passing the liver via collateral venous channels.

\section{ACKNOWLEDGMENTS}

We wish to thank Dr. J. D. Nabarro, Professor M. L. Rosenheim, Dr. J. F. Stokes, and Dr. W. Aldren Turner for permission to investigate their patients; Mr. Alan Hunt and Professor R. S. Pilcher who carried out the lieno-renal shunts on G. M. and A. R., respectively; also Dr. F. V. Flynn for the routine liver function tests reported in Table I.

\section{REFERENCES}

1. Reed, G., The polarographic estimation of cystine in urine. J. Biol. Chem., 1942, 142, 61.

2. Dent, C. E., and Harris, H., The genetics of 'cystinuria.' Ann. Eugenics, Lond., 1951, 16, 60.

3. Frankl, W., Martin, H., and Dunn, M. S., The apparent concentration of free tryptophan, histidine and cystine in pathological human urine measured microbiologically. Arch. Biochem., 1947, 13, 103.

4. Dunn, M. S., Akawaie, S., Yeh, H. L., and Martin, H., Urinary excretion of amino acids in liver disease. J. Clin. Invest., 1950, 29, 302.

5. Dent, C. E., and Walshe, J. M., Amino-acid metabolism in liver disease in Liver Disease. Philadelphia, Blakiston, 1951, p. 22.

6. Walshe, J. M., Disturbances of aminoacid metabolism following liver injury, a study by means of paper chromatography. Quart. J. Med., 1953, N.S. 22, 483.

7. Kolthoff, I. M., and Lingane, J. J., Polarography. 2nd Ed., New York, Interscience, 1946.

8. Dent, C. E., Senior, B., and Walshe, J. M., The pathogenesis of cystinuria. II. Polarographic studies of the metabolism of sulphur-containing aminoacids. J. Clin. Invest., 1954, 33, 1216.

9. Stein, W. H., Bearn, A. G., and Moore, S., The amino acid content of the blood and urine in Wilson's disease. J. Clin. Invest., 1954, 33, 410.

10. Stein, W. H., A chromatographic investigation of the amino acid constituents of normal urine. J. Biol. Chem., 1953, 201, 45. 
11. Brdicka, R., quoted by Kolthoff, I. M., and Lingane, J. J. in Polarography. 2d ed., New York, Interscience, 1946, p. 409.

12. Dent, C. E., Heathcote, J. G., and Joron, G. E., The pathogenesis of cystinuria. I. Chromatographic and microbiological studies of the metabolism of sulphur-containing amino-acids. J. Clin. Invest., 1954, 33, 1210.

13. Dent, C. E., and Harbury, M., Personal communication.
14. Harris, H., and Warren, F. L., Quantitative studies on the urinary cystine in patients with cystine stone formation and in their relatives. Ann. Eugenics, Lond., 1953, 18, 125.

15. Dent, C. E., and Rose, G. A., Aminoacid metabolism in cystinuria. Quart. J. Med., 1951, N.S. 20, 205.

16. Brand, E., Cahill, G. F., and Harris, M. M., Cystinuria. II. The metabolism of cystine, cysteine, methionine, and glutathione. J. Biol. Chem., 1935, 109, 69. 